\title{
Determination of free- and protein primary amino acids in biological materials by high-performance liquid chromatography and photodiode array detection
}

\author{
M. Czauderna, J. Kowalczyk, K.M. Niedźwiedzka and I. Wąsowska
}

\author{
The Kielanowski Institute of Animal Physiology and Nutrition, \\ Polish Academy of Sciences \\ 05-110 Jablonna, Poland
}

(Received 5 January 2002; accepted 31 January 2002)

\section{ABSTRACT}

Work from this laboratory resulted in improved high-performance liquid chromatography methods for quantification of free- and protein primary amino acids in biological materials. Biological samples were hydrolyzed with $6 \mathrm{M} \mathrm{HCl}$ for $20 \mathrm{~h}$ at $104 \pm 2{ }^{\circ} \mathrm{C}$. Primary amino acids, with the exception of tryptophan, were separated after pre-column derivatization with o-phthaldialdehyde (OPA) in the presence of ethanethiol (ESH). Derivatized amino acids were analyzed using a Nova Pak $\mathrm{C}_{\mathrm{ix}}$ column $(4 \mu \mathrm{m}, 250 \times 4.6 \mathrm{~mm}$ I.D., Waters) by quaternary gradient system I. Detection was carried out simultaneously using UV monitoring at $337 \mathrm{~nm}$ and fluorescence detection $\left(\lambda_{\mathrm{ex}} / \lambda_{\mathrm{erm}}=336 / 425 \mathrm{~nm}\right)$. Derivatized amino acids were completely resolved from all interfering species in about $50 \mathrm{~min}$. HPLC system I with two detection modes can also be used for quantification of free primary amino acids in ovine blood plasma. A trace amount of cysteine as its OPA/ESH derivative can be quickly quantified $(\sim 3.5 \mathrm{~min})$ using an isocratic HPLC system with UV detection at $274 \mathrm{~nm}$. Separation and quantification of tryptophan in alkaline hydrolysates was achieved without derivatization using the same HPLC column by ternate gradient elution system Il with UV monitoring at $219 \mathrm{~nm}$ or fluorescence detection $\left(\lambda_{\mathrm{cx}} / \lambda_{\mathrm{ctm}}=280 / 360 \mathrm{~nm}\right)$. The obtained average recoveries of assayed amino acids added to biological samples were near $100 \%$ when UV and fluorescence detection were applied. Generally, fluorescence detection in comparison with UV monitoring offers lower limits of detection (0.04-1.25 vs $\left.0.05-12.7 \mu \mathrm{mol} \cdot 1^{-1}\right)$ and quantification $\left(0.12-11.7 \mathrm{vs} 0.18-42.0 \mu \mathrm{mol} \cdot \cdot^{-1}\right)$, however, the sensitivity of the UV detection mode is satisfactory for accurate and precise quantification of free- and protein amino acids in biological materials. The HPLC systems with UV detection assured better resolution of amino acid peaks in comparison with fluorescence detection. Satisfactory purity of analytical amino acid peaks (near 100\%) and precision of HPLC systems with both detection modes renders these procedures suitable for routine analysis of amino acid concentrations in large numbers of 
biological samples. HPLC system I enabled quantification of 2,6-diaminopimelic acid, so the current chromatographic system can also be applied for the estimation of bacterial protein production in ruminants.

KEY WORDS: amino acids, pre-column derivatization, HPLC, UV detection, fluorescence detection

\section{INTRODUCTION}

The response of animals to feed protein (PN) and non-protein nitrogen sources (NPN) basically depends on the amount and nature of feed protein and amino acids absorbed from the small intestine. In recent years much interest has focused on covering amino acid requirements of animals for growth, development and productivity (Batterham, 1992; Lewis and Bayley, 1995; Żcbrowska and Buraczewska, 1998; Ravindran and Bryden, 1999). Thus, because amino acid composition is so important, physiologists, geneticists or nutritionists should be interested in developing more accurate and precise amino acid analyses. Although there are many techniques for this analysis, the application of commercial amino acids analyzers using ion-exchange liquid chromatography is by far the most popular ( $\mathrm{Ng}$ et al., 1991; Moller, 1993; Sarwar and Botting, 1993; Williams, 1994). However, many high performance liquid chromatography (HPLC) methods and gas chromatography techniques (GC) for quantification of amino acids have also been published in recent years (Sarwar and Botting, 1993; Cohen and Michaud, 1998; Czauderna and Kowalczyk, 1998; Peter et al., 1998; Albin et al., 2000; Polak and Golkiewicz, 2000; Kutlan and Molnar-Perl, 2001; Molnar-Perl, 2001).The major shortcomings of automatic amino acid analyzers for amino acids observed are long analysis time and inadequate detection limits, dedication of the analyzers to only amino acid analysis, and high cost of the instruments. On the other hand, the use of reversed-phase HPLC with pre-column derivatization for the analysis of protein- and free amino acids is becoming established as a cheaper alternative to commercial amino acid analyzers. Five main pre-column derivatization (o-phthaldialdehyde (OPA), phenylthiohydantoin, phenylthiocarbamyl, dansyl chloride and dabsyl chloride) HPLC methods were compared in terms of detection limit, precision, resolution, stability and duration of analysis (Sarwar and Botting, 1993 ). The rapid OPA derivatization procedure has become popular because the reagent itself does not fluoresce, the instrumentation in pre-column derivatization is simpler and the cost of such systems is lower compared with post-column derivatization or amino acid analyzers (Rattenbury, 1981; Sarwar and Botting, 1993; Williams, 1994). Moreover, fluorescent OPA derivatives were found to be most desirable in terms of quantitation limits and analysis time. Unfortunately, the main disadvantage of the OPA method lies in the fact that OPA does not react with imino acids (i.e., secondary amino acids: proline and hydroxyproline). 
As the OPA derivatization method is suitable for automation, this procedure can be used in routine determination of primary amino acids in biological samples. Therefore, the main purpose of our work was to find a more versatile HPLC method with UV detection than previously published for OPA amino acid assay in biological samples (Czauderna and Kowalczyk, 1998, 1999). Because OPA derivatization is known to be more sensitive than ninhydryn colorimetry, we also tried to improve a new HPLC system with fluorescence detetection.

\section{MATERIAL AND METHODS}

\section{Reagents}

All reagents were of analytical grade, whereas organic solvents were HPLC grade. Tetrahydrofuran and methanol were purchased from POCh Gliwice (Poland). Ethanethiol $(\mathrm{ESH})$ and 2-mercaptoethanol $(\mathrm{E}(\mathrm{OH}) \mathrm{SH})$ were obtained from Aldrich (Germany); 0-phthaldialdehyde (OPA) and all amino acids used were from Sigma (St. Louis, MO, USA). Water used for the preparation of mobile phases and chemical reagents was prepared using an $\mathrm{Elix}^{\mathrm{TM}}$ water purification system (Millipore). The mobile phases were filtered through a $0.45 \mu \mathrm{m}$ membrane filter (Millipore).

\section{Chromatographic equipment}

An Alliance separation module (model 2690, Waters) with a Waters 474 fluorescence detector and a Waters 996 photodiode array detector (PAD) was used for the gradient elution systems. An Alliance autosampler was thermostated at $\sim 5^{\circ} \mathrm{C}$. The OPA derivatives were simultaneously monitored using PAD and fluorescence detectors. The PAD was operated in a UV range from 190 to $400 \mathrm{~nm}$ with a spectral resolution of $1.2 \mathrm{~nm}$ and a measurement frequency of 1 spectrum per second. The fluorescence detections were taken at the optimum excitation and emission wavelengths: at $\lambda_{\mathrm{cx}} / \lambda_{\mathrm{cm}}=336 / 425 \mathrm{~nm}$. Development of the gradient systems, collection and data integration were performed using Millennium 2001 software (version 2.15) and a Pentium III computer (Compaq). The ambient temperature was $20-22^{\circ} \mathrm{C}$. The analytical column used was a Nova Pak $\mathrm{C}_{18}$ column $(4 \mu \mathrm{m}$, $250 \times 4.6 \mathrm{~mm}$, I.D., Waters) in conjunction with a guard Nova Pak column (Waters) of $10 \times 6 \mathrm{~mm}$ containing $\mathrm{RP}$ phase $\mathrm{C}_{18}(30-40 \mu \mathrm{m})$ pellicular packing material.

\section{Analytical mobile phases and the gradient elution system}

Two gradient elution systems were used for complete separation and detection of amino acids in the assayed biological samples. The following elution mobile phases 
were used: solvent A was tetrahydrofuran - buffer A $(1: 99, \mathrm{v} / \mathrm{v})$. The buffer A for mobile phase $\mathrm{A}$ was prepared from $0.02 \mathrm{M} \mathrm{Na}_{2} \mathrm{HPO}_{4}$ adjusted to $\mathrm{pH} 3.5$ with $\sim 10 \%$ phosphoric acid. The solvent $B$ was tetrahydrofuran - buffer $B(1: 99, v / v)$. The buffer $\mathrm{B}$ for mobile phase $\mathrm{B}$ was prepared from $0.04 \mathrm{M} \mathrm{Na}_{2} \mathrm{HPO}_{4}$ adjusted to $\mathrm{pH}$ 6.6 with $\sim 10 \%$ phosphoric acid. Solvent $C$ was methanol, while solvent D was water. For analysis of derivatized amino acids in standards and biological samples, clution was carried out in quaternary gradient system I (Table 1); all separations were performed at a column temperature of $37^{\circ} \mathrm{C}$. For direct analysis of tryptophan, ternate gradient system II (Table 2) using simultaneous UV detection (at $279 \mathrm{~nm})$ and fluorescence detection $\left(\lambda_{\mathrm{ex}} / \lambda_{\mathrm{em}}=280 / 360 \mathrm{~nm}\right)$ was applied. All direct assays of tryptophan were carried out at a column temperature of $31^{\circ} \mathrm{C}$. The minimal system pressure was $25.5 \pm 0.1 \mathrm{MPa}$, the maximal pressure was $36.3 \pm 0.2 \mathrm{MPa}$. Injection volumes were 5-40 $\mu \mathrm{l}$. Amino acids were identified by the retention time of processed standards injected separately and by adding standard solutions to bio-

TABLE L

Quaternary gradient elution system I used for analysis of OPA/ESH amino acids derivatives in biological samples hydrolysed with $6 \mathrm{M} \mathrm{HCl}$ (column temperature $37^{\circ} \mathrm{C}$ )

\begin{tabular}{lcccc}
\hline Time & \multicolumn{4}{c}{ Composition $^{b} \%$} \\
\cline { 2 - 5 } min & Solvent A & Solvent B & Solvent C & Solvent D \\
\hline 0 & 0 & 85 & 15 & 0 \\
1.8 & 0 & 85 & 15 & 0 \\
3.0 & 0 & 72 & 28 & 0 \\
19.0 & 0 & 72 & 28 & 0 \\
19.5 & 0 & 64 & 36 & 0 \\
22.0 & 0 & 64 & 36 & 0 \\
28.0 & 0 & 54 & 46 & 0 \\
30.2 & 55 & 0 & 45 & 0 \\
30.5 & 44 & 0 & 56 & 0 \\
35.5 & 43 & 0 & 57 & 0 \\
37.0 & 0 & 44 & 56 & 0 \\
42.0 & 0 & 37 & 63 & 0 \\
$45.0^{c}$ & 0 & 40 & 60 & 15 \\
46.5 & 0 & 0 & 85 & 15 \\
$53.0^{\text {d }}$ & 0 & 0 & 85 & \\
\hline
\end{tabular}

- flow-rate: $1.8 \mathrm{ml} / \mathrm{min}$

b - all changes of solvents composition were linear

c - after $45 \mathrm{~min}$, the gradient composition: solvent C (methanol)/solvent D (water) - 69:31 (v/v) was chosen as the optimum separation of lysine from interfering endogenous species in blood plasma (modification for fractionation of free amino acids in ovine blood plasma)

$d$ - after $53 \mathrm{~min}$, the column was re-equilibrated for $10 \mathrm{~min}$ in $85 \%$ solvent $\mathrm{B}$ and $15 \%$ solvent $\mathrm{C}$ at a flow-rate of $1.8 \mathrm{ml} / \mathrm{min}$ 
TABLE 2

Ternate gradient system II used for direct analysis of tryptophan (column temperature $31^{\circ} \mathrm{C}$ )

\begin{tabular}{lcccc}
\hline \multirow{2}{*}{$\begin{array}{l}\text { Time } \\
\min \end{array}$} & $\begin{array}{c}\text { Flow rate } \\
\text { ml/min }\end{array}$ & Solvent B & Colvent C & Solvent D \\
\cline { 2 - 5 } & 1.9 & 100.0 & 0 & 0 \\
5.0 & 1.9 & 100.0 & 0 & 0 \\
8.5 & 1.9 & 94.2 & 5.8 & 0 \\
9.0 & 2.0 & 0 & 95.0 & 5.0 \\
19.5 & 2.1 & 0 & 95.0 & 5.0 \\
19.8 & 1.9 & 0 & 75.0 & 25.0 \\
20.0 & 1.9 & 100.0 & 0 & 0 \\
30.0 & 1.9 & 100.0 & 0 & 0 \\
\hline
\end{tabular}

a - all changes of solvents composition were linear

logical samples. The limits of detection (LOD) were calculated as a signal-to-noise ratio of 3 , while the limit of quantification (LOQ) was defined as 10 times the noise under a peak (Gratzfeld-Husgen and Schuster, 1996; Meyer 1999).

\section{Preparation of the borate buffer}

Boric acid, $2.474 \mathrm{~g}$, was dissolved in $80 \mathrm{ml}$ of water and the $\mathrm{pH}$ was adjusted to 9.8-9.9 with $5 \mathrm{M} \mathrm{KOH}$. The resulting solution was filtered through filter paper and then diluted to a volume of $100 \mathrm{ml}$ to make $0.4 \mathrm{M}$ borate buffer.

\section{Preparation of derivatizing reagent (OPA/ESH)}

Seventy-five $\mathrm{mg}$ of OPA were dissolved in $4.5 \mathrm{ml}$ methanol and $0.5 \mathrm{ml}$ borate buffer. Next, $70 \mu \mathrm{I}$ of ethanetiol (ESH) were added and the resulting solution was mixed. The reagent solution was prepared at least $2 \mathrm{~h}$ before use. It is recommended to protect the derivatizing solution from light and to store refrigerated $\left(-18^{\circ} \mathrm{C}\right)$ when not in use. This solution was retained no longer than two weeks. The reagent strength was maintained by addition of $10 \mu \mathrm{l}$ of ESH cvery 2-3 days.

Preparation and hydrolysis of biological samples with $6 \mathrm{M} \mathrm{HCl}$

Samples of biological materials as rumen bacteria (Lachnospira multiparus 685), ovine duodenal digesta, faeces, meat and milk were frozen, freeze-dried and the obtained homogeneous materials (about 400-500 mg) were hydrolyzed with $50 \mathrm{ml}$ of $6 \mathrm{M} \mathrm{HCl}$ at $104 \pm 2^{\circ} \mathrm{C}$ for $20 \mathrm{~h}$ in sealed tubes. After cooling the hydrolysates were filtered through filter paper and washed three times with water. Hy- 
drochloric acid was removed from the filtrates in a vacuum rotary evaporator. Ten milliliters of water were added to the residue and then evaporated to dryness again in vacuum to remove residues of $\mathrm{HCl}$. This evaporating procedure was repeated two times. The residues were stored at $-18^{\circ} \mathrm{C}$ when not in use. The residue was redissolved in $1 \mathrm{ml}$ of the borate buffer ( $\mathrm{pH} 9.8-9.9$ ). 10-40 $\mu$ l of resulting solution was used for the OPA/ESH derivatization procedure as below.

\section{Procedure for preparation of the hydrolysate for tryptophan determination}

Lyophilized homogeneous pea seeds (i.e. $\sim 500 \mathrm{mg}$ ) was weighed (sample corresponding to $20 \mathrm{mg} \mathrm{N}$ ) into $50 \mathrm{ml}$ plastic bottles and mixed with $14 \mathrm{~g} \mathrm{Ba}(\mathrm{OH})_{2} \cdot \mathrm{H}_{2} \mathrm{O}$ and $15 \mathrm{ml} \mathrm{H}_{2} \mathrm{O}$ (Buraczewska and Buraczewski, 1984). Then 3 drops of octyl alcohol were added and the bottles were covered with glass stoppers. Hydrolysis lasted $16 \mathrm{~h}$ in an autoclave at $123^{\circ} \mathrm{C}$. After the hydrolysis the content of the bottle was transferred with hot water into beakers, cooled in an ice-water bath and treated with 3 to $3.5 \mathrm{ml}$ conc. $\mathrm{H}_{2} \mathrm{SO}_{4}$ for barium precipitation. The sample was then mixed occasionally and kept in the bath about $25 \mathrm{~min}$. Afterwards the sample was transferred into $100 \mathrm{ml}$ tubes for centrifugation. The supernatant was checked for complete barium precipitation and the precipitate washed twice with hot water followed by centrifugation. The collected supernatant was adjusted to $\mathrm{pH} \sim 7$ with $2 \mathrm{M} \mathrm{NaOH}$ and the volume was made up to $90 \mathrm{ml}$ with water. The appropriate volumes $(10-20 \mu \mathrm{l})$ of resulting solution were directly introduced into the HPLC system just after preparation. It is recommended to protect the hydrolysates from light and to store refrigerated $\left(-18^{\circ} \mathrm{C}\right)$ when not in use.

Preparation of ovine blood plasma for firee amino acid HPLC analysis

Blood samples from the jugular vein of sheep were collected into heparinized tubes (kept in an ice bath) and centrifuged at $2000 \mathrm{~g}$ for $15 \mathrm{~min}\left(\right.$ at $0-4^{\circ} \mathrm{C}$ ). The plasma was stored at $-18^{\circ} \mathrm{C}$. On the day of analysis, $1 \mathrm{ml}$ of plasma $\left(0-1^{\circ} \mathrm{C}\right)$ was deproteinized with $1 \mathrm{ml}$ of $7 \%$ cooled solution $\left(0-1^{\circ} \mathrm{C}\right)$ of trichloroacetic acid and centrifuged at $2000 \mathrm{~g}$ for $15 \mathrm{~min}\left(\right.$ at $0-4^{\circ} \mathrm{C}$ ).

The obtained supernatant was filtered through a $0.2-\mu \mathrm{m}$ nylon filter (Cole Parlmers) into an autosampler vial. $100-150 \mu \mathrm{l}$ of supernatant was used for the OPA/ ESH derivatization procedure as below.

\section{Derivatization procedure}

To an autosampler reacti-vial were added an appropriate volume (20-50 $\mu \mathrm{l})$ of assayed biological sample, $1 \mathrm{ml}$ of OPA/ESA derivatizing reagent and $10 \mu \mathrm{l}$ of $1 \mathrm{M}$ $\mathrm{NaOH}$. The contents were mixed and reacted for $3 \mathrm{~min}$ at room temperature. The 
$\mathrm{pH}$ of the resulting solution should be from 9 to 10 . At the end of the 3 min derivatization period, the processed samples were injected on to the HPLC column. Thus, the total time of the reaction was constant: ca $4 \mathrm{~min}$. The derivatizing procedure for standards was the same as for biological samples. It is recommended to protect all derivatized samples from the light and to store them at $-18^{\circ} \mathrm{C}$ until analyzed.

\section{RESULTS AND DISCUSSION}

The aim of this work was to extend our earlier investigations (Czauderna and Kowalczyk, 1998, 1999) in order to determine the possibility of free- and protein amino acid assays in biological materials. Interest in amino acid analysis has grown because information on the amino acid requirements, especially essential and semiessential amino acids, in animal nutrition has great economic value, permitting the formulation of diets to meet amino acid requirements without useless excess. Therefore, recently many methods for amino acid quantification have been rapidly developed. In fact, in the last several years some characteristics of OPA/ESH and $\mathrm{OPA} / \mathrm{E}(\mathrm{OH}) \mathrm{SH}$ amino acid derivatives have been identified (Czauderna and Kowalczyk, 1998, 1999; Molnar-Perl, 2001). Exhaustive investigations have demonstrated that $\mathrm{OPA} / \mathrm{E}(\mathrm{OH}) \mathrm{SH}$ and OPA/ESH amino acid derivatives can be successfully resolved by gradient RP-HPLC with fluorescence detection (Sarwar and Botting, 1993; Czauderna and Kowalczyk, 1998, 1999; Kutlan and Molnar-Perl, 2001; Molnar-Perl, 2001). Therefore in the presented paper, on the basis of our earlier experience (Czauderna and Kowalczyk, 1998, 1999), a new gradient HPLC system with UV detection for primary amino acids has been developed. Our earlier work (Czauderna and Kowalczyk, 1998) showed that clear resolution of OPA/ $\mathrm{E}(\mathrm{OH}) \mathrm{SH}$ amino acid derivatives can be obtained using a Nova Pak $\mathrm{C}_{18}$ column ( $4 \mu \mathrm{m}, 250 \times 4.6 \mathrm{~mm}$ I.D., Waters) and fluorescence detection. Thus, after detailed investigations of the influence of column temperature, mobile phase composition and the $\mathrm{pH}$ of buffers on resolution of derivatized amino acids, the use of a Nova Pak $\mathrm{C}_{18}$ column, the OPA/ESH derivatizing reagent and $37^{\circ} \mathrm{C}$ elution temperature were chosen as optimum separation conditions of all assayed primary amino acids using UV detection at $337 \mathrm{~nm}$. As shown in Figures $1 \mathrm{~A}$ and $\mathrm{B}$, in the quaternary gradient system (Table 1) developed in the presented study, OPA/ESH amino acid derivatives are substantially retained on the column (in contrast to $\mathrm{OPA} / \mathrm{E}(\mathrm{OH}) \mathrm{SH}$ amino acid derivatives) and clearly distinct from unidentified species, background interference and endogenous substances present in all assayed samples. To enhance the resolution of amino acids eluted between $\sim 6$ and $\sim 31 \mathrm{~min}$, buffer $\mathrm{B}$ should be prepared from $0.04 \mathrm{M} \mathrm{Na}_{2} \mathrm{HPO}_{4}$ and adjusted to $\mathrm{pH} 6.6$, while to increase the resolution between methionine and valine, buffer $\mathrm{A}$ should be prepared from $0.02 \mathrm{M} \mathrm{Na}_{2} \mathrm{HPO}_{4}$ and adjusted to $\mathrm{pH} 3.5$. The water used in the last gradient 
step (Table 1) as the mobile phase $D$, resulted in low system pressure (especially after 46 min of HPLC run) and excellent peak shapes, close to symmetrical even with analyte elution times to $\sim 50 \mathrm{~min}$. As can be seen from the chromatograms (Figure $1 \mathrm{~A}$ and B), the gradient system developed in this study and applied UV detection mode were found to provide excellent baseline stability (like in the fluorescence detection mode). Obviously, all assayed amino acid peaks were absent from the blank, when the developed gradient program was used. So, all fractionate derivatized primary amino acids can be easily quantified using Millennium software. Based on UV spectra of OPA/ESH amino acid derivative spectra (Figure 1C) and blank chromatographic measurements, UV detection at $337 \mathrm{~nm}$ was found to produce the greatest signal (i.e. a peak area) and low background under analytical peaks. Subsequently, attempts were made to compare the results of amino acid quantification depending on the detection modes used. Table 3 summarizes the comparison of responses of the PAD and fluorescence detectors and shows that derivative measurements at $337 \mathrm{~nm}$ can provide a second satisfactory alternative UV detecting mode. As expected, the responses of the PAD detector to the concentration of the assayed amino acids are linear functions. In fact, the correlation coefficients ( $r$ ) and standard error in slopes (SES) evidenced that monitoring at $337 \mathrm{~nm}$ provided generally better linearity of amino acid derivative responses than fluorescence detection (at $\lambda_{\mathrm{ex}} / \lambda_{\mathrm{em}}=336 / 425 \mathrm{~nm}$ ). Detailed analysis of chromatograms revealed that, also, better resolution of amino acid derivatives was obtained using UV detection in comparison with fluorescence detection. Moreover, UV detection at $337 \mathrm{~nm}$ produced generally only 2-3 smaller signals than the fluorescence emission signal $\left(\lambda_{\mathrm{ex}}=425 \mathrm{~nm}\right)$ obtained by applying the $336 \mathrm{~nm}$ excitation wavelength. The results of 2,6-diaminopimelic acid (DAPA) quantification are particularly important (Table 3) because the UV and fluorescence detection produced practically the same signals (i.e. peak areas). In other words, the presented method with UV monitoring produced a new valuable analytical tool for determining trace amounts of DAPA (important as a marker of bacterial protein production in ruminants) (Robinson et al., 1996; Czauderna and Kowalczyk, 1999; McKerrow et al., 2000) in the presence of a large excess of other amino acids. Consequently, HPLC system I with UV detection can be simultaneously applied for primary amino acid assays and for the estimation of ruminal bacterial protein supply to ruminants. Furthermore, our quaternary gradient program fractionates cysteine and cystine from other primary amino acid derivatives and background fluctuations. These sulphur-containing amino acids can be easily quantified by UV monitoring at $337 \mathrm{~nm}$. As shown in Figure $1 \mathrm{~A}$ (chromatogram $\mathrm{A}$ ) a cysteine peak had a retention time of $4.56 \pm 0.03$ min (mean \pm SD of 8 HPLC runs), while a cystine peak had a retention time of $45.40 \pm 0.12 \mathrm{~min}$ (mean \pm SD of 9 HPLC runs). Moreover, the cysteine derivative could be differentiated from other amino acid derivatives by the use of a photodiode array detector (PAD). As can be seen from UV spectra (Figure $1 \mathrm{C}$ ), derivatized 


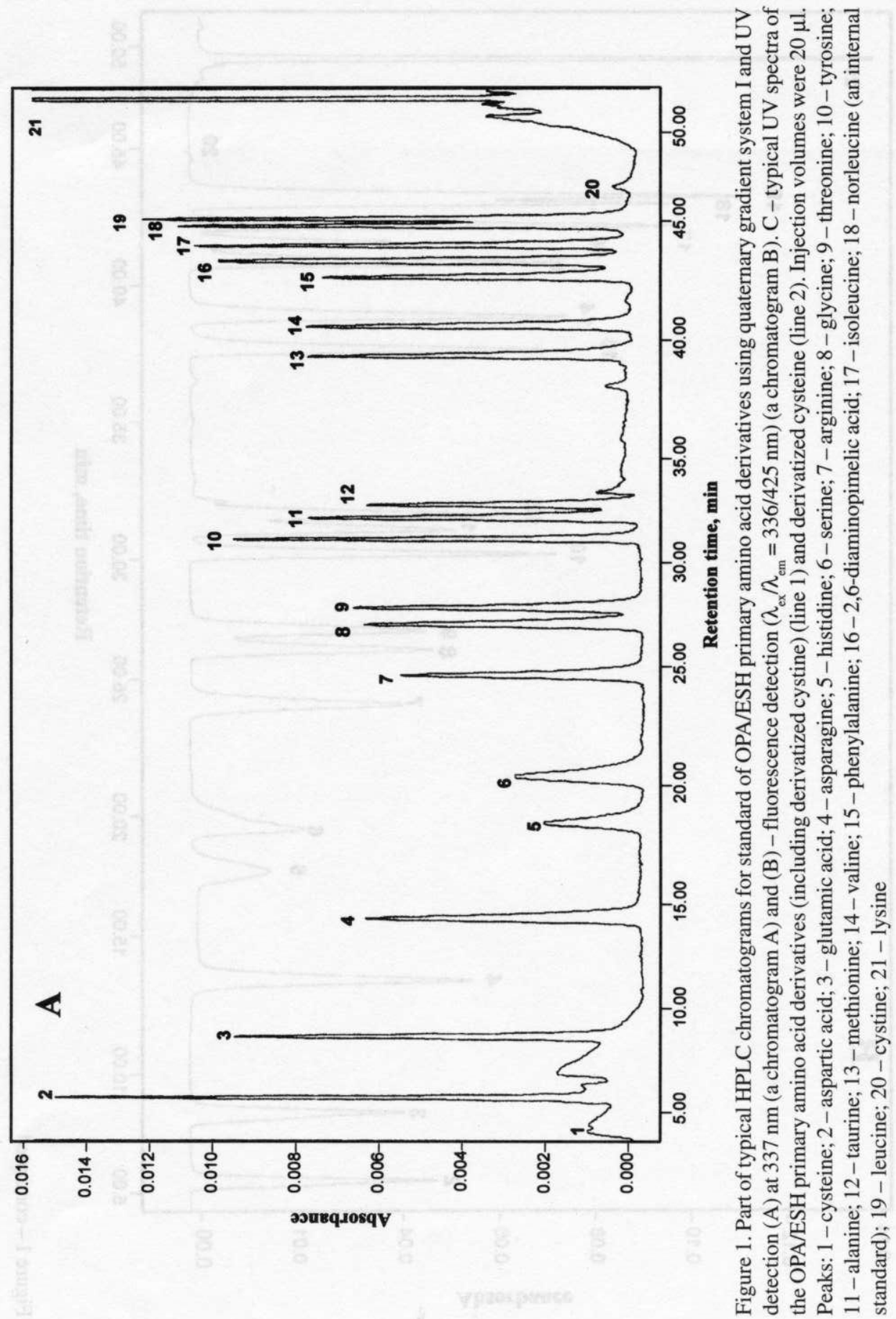









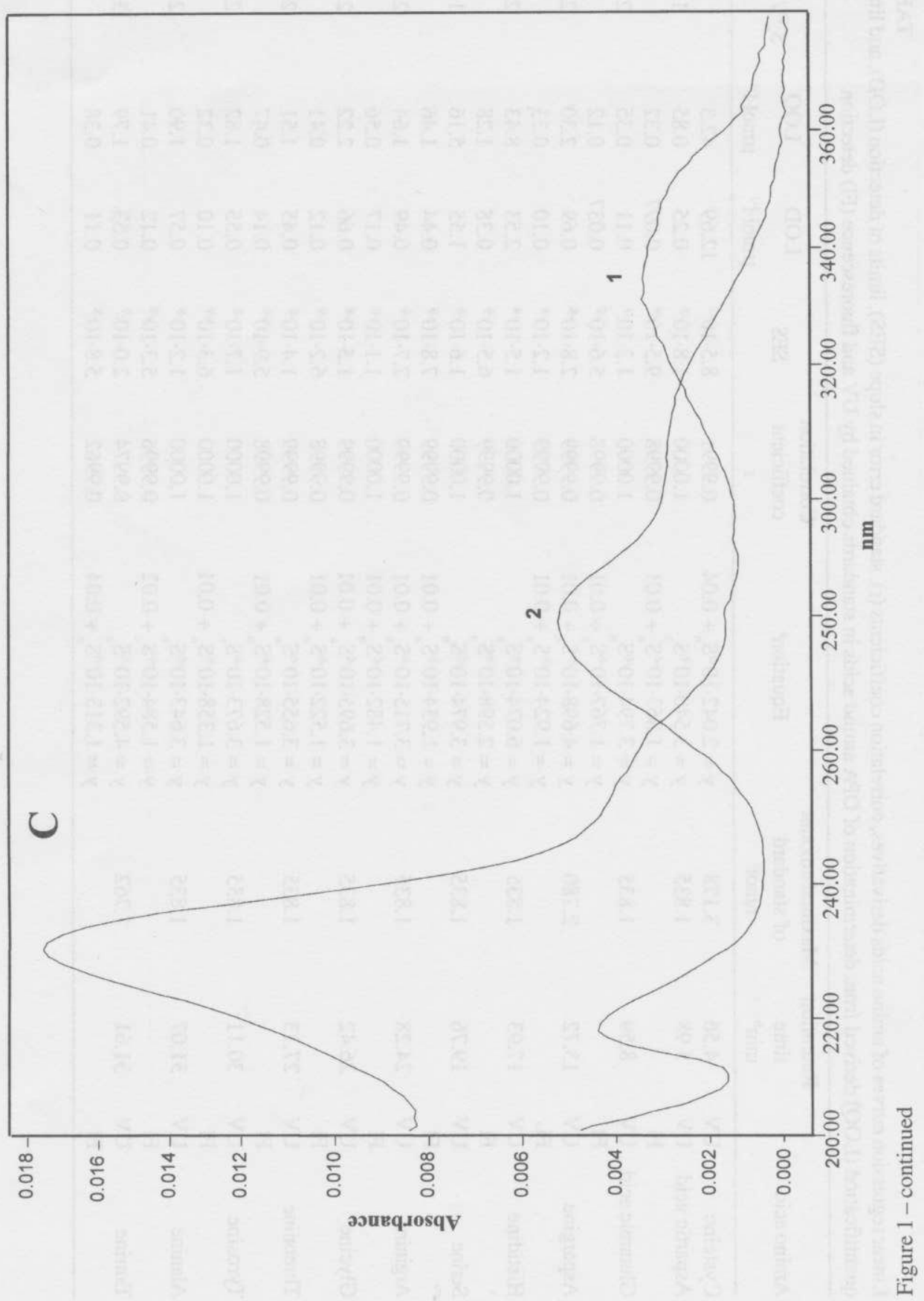







递

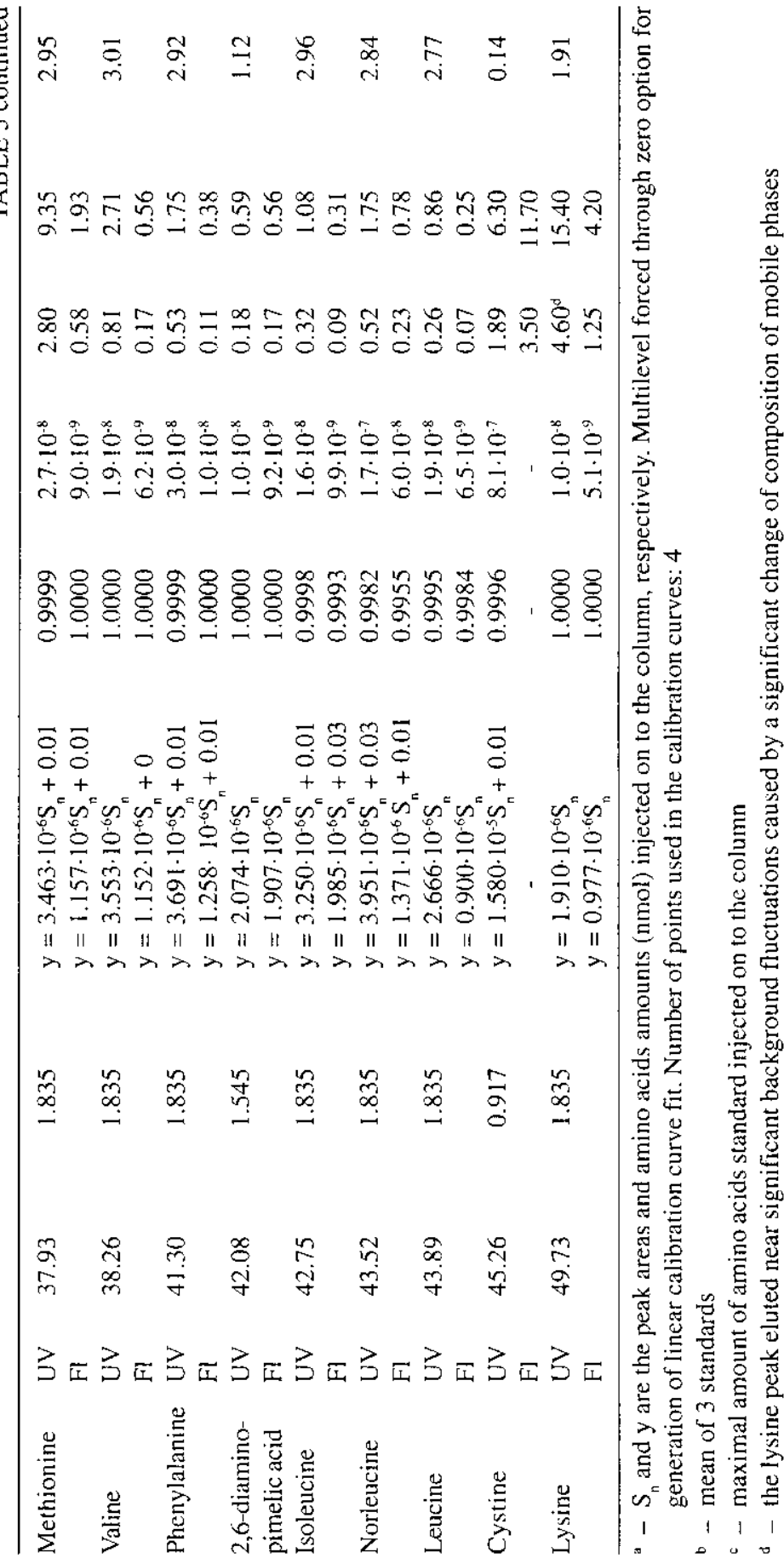


cysteine showed a very high and broad band in the spectral range from 220 to $360 \mathrm{~nm}$ with the maximum at 282-284 $\mathrm{nm}$. However, UV detection at $337 \mathrm{~nm}$ should be used for the clear distinction of the derivatized cysteine peak from background interference and endogenous substances present in ovine samples. Obviously, these amino acids cannot be quantified using a fluorescence detector (Figure $1 \mathrm{~B}$ ) because fluorescence detection of cysteine and cystine derivatives gave very low responses in comparison with UV detection (Table 3 ). Unfortunately, main disadvantage of derivatized cysteine is its serious instability; after $2 \mathrm{~h}$ of storage at $-18^{\circ} \mathrm{C}$, the OPA/ESH cysteine derivative exhibited ca. $85 \%$ degradation. On the other hand, the cystine derivative is more stable than converted cysteine. Other primary amino acids, however, formed more stable derivatives in comparison with cystine.

The low values of the limit of detection (LOD) and limit of quantification (LOQ) for derivatized amino acids point to the satisfactory sensitivity of the proposed UV detection mode. As the presented method was applied to lyophilized samples (feeds, bacteria, intestinal digesta, faeces, blood plasma, meat and milk), sensitivity can be reduced several times, however, it seems clear from the LOD and LOQ values that the proposed method offers satisfactory sensitivity permitting detection and quantification of a relatively low level of amino acids when compared with the original amino acid contents in all assayed biological samples.

\section{Direct determination of tryptophan}

Tryptophan possess a relatively high absorbance band in the short UV range (absorbance maximum at $219 \mathrm{~nm}$ ) and a lower one (a chromophore) in the spectral range from 245 to $290 \mathrm{~nm}$ with the absorbance maximum at $\sim 279 \mathrm{~nm}$ (Figure 2A). Therefore, a simple gradient elution program (Table 2) with fluorescence detection $\left(\lambda_{\mathrm{ex}} / \lambda_{\mathrm{em}}=280 / 360 \mathrm{~nm}\right.$ ) and UV monitoring at 219 and $279 \mathrm{~nm}$ can be used for direct determination of tryptophan in biological samples. Fortunately, tryptophan can be differentiated from tyrosine and phenylalanine by the use of the photodiode array detector, because they possess different UV spectra (Figure 2A). Obviously, all other amino acids present in alkaline hydrolysates are transparent in the applied UV range. As shown in Figure $2 \mathrm{~A}$ and $\mathrm{B}$, in the proposed elution system II, underivatized tryptophan was substantially retained on the $C_{18}$ Nova Pak column, and was completely separated from tyrosine (the average retention time: $1.97 \mathrm{~min}$ ), phenylalanine (average retention time: $2.89 \mathrm{~min}$ ), background interference and unidentified species. Thus, basing on above results it can be suggested that short-UV monitoring (at $219 \mathrm{~nm}$ ) should also be used for direct determination of tryptophan. As expected, the tryptophan peak having a retention time of $5.71 \pm 0.11 \mathrm{~min}$ (mean \pm SD of 9 samples) was absent from the blank when the HPLC system II with UV (at 279 and $219 \mathrm{~nm}$ ) and fluorescence detection was used. As can be 


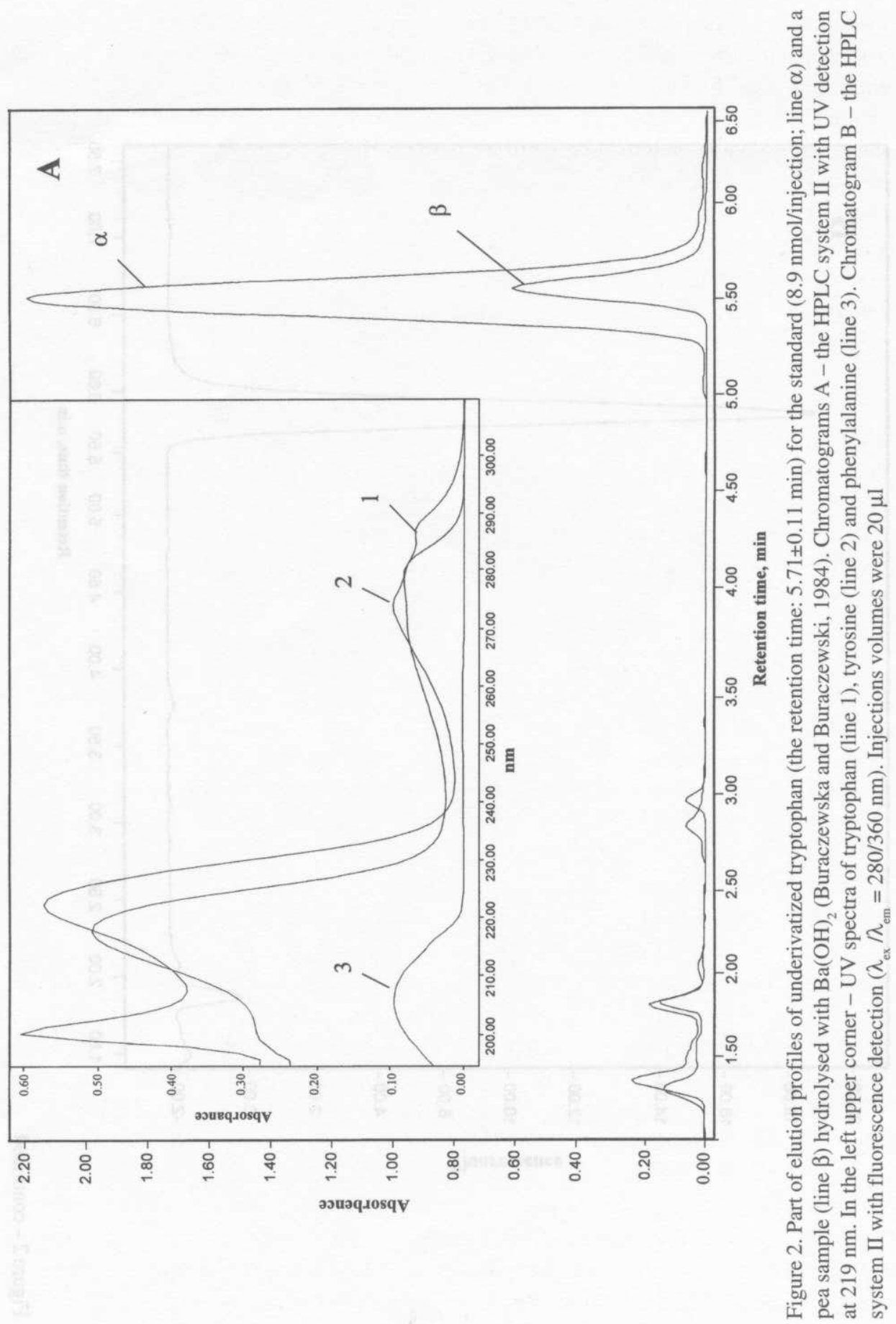







TABLE 4

Summary of HPLC analyses of underivatized tryptophan standard: comparison of three detection modes (gradient elution system II)

\begin{tabular}{|c|c|c|c|}
\hline \multirow{2}{*}{ Parameter } & \multicolumn{2}{|c|}{ UV detection } & \multirow{2}{*}{$\begin{array}{l}\text { Fluorescence detection } \\
\lambda_{\mathrm{ex}} / \lambda_{\mathrm{en}}=280 / 360 \mathrm{~nm}\end{array}$} \\
\hline & at $219 \mathrm{~nm}$ & at $279 \mathrm{~nm}$ & \\
\hline Linear regression curves & $y=2.51 \times 10^{-7} S_{n}+0.08$ & $y=1.70 \times 10^{-6} S_{n}+0.3$ & $y=1.14 \times 10^{-6} S_{n}+0.02$ \\
\hline Correlation coefficient ( $r)$ & 0.99963 & 0.99977 & 0.99967 \\
\hline $\begin{array}{l}\text { Standard error } \\
\text { in slope (SES) }\end{array}$ & $4.0 \times 10^{-9}$ & $2.6 \times 10^{-8}$ & $2.5 \times 10^{-8}$ \\
\hline $\begin{array}{l}\text { Limit of detection } \\
\text { (LOD), } \mu \mathrm{mol} \cdot]^{\cdot 1}\end{array}$ & 0.054 & 0.304 & 0.210 \\
\hline $\begin{array}{l}\text { Limit of quantification } \\
(\mathrm{LOQ}), \mu \mathrm{mol} \cdot]^{-1}\end{array}$ & 0.180 & 1.010 & 0.699 \\
\hline $\begin{array}{l}\text { Values of peak } \\
\text { areas ratio }{ }^{b}\end{array}$ & $\mathrm{~S}_{n}{ }^{219 n \mathrm{~m} / \mathrm{S}} / \mathrm{S}=4.5$ & $\mathrm{~S}_{12}{ }^{274 n \mathrm{~nm}} / \mathrm{S}_{11}=0.73$ & - \\
\hline
\end{tabular}

a $-S_{13}$ and $y$ are the peak areas and tryptophan amount $(\mu \mathrm{g})$ in standard, respectively. Multilevel forced through zero option for generation of linear calibration curve fit. Number of points used in the calibration curves: 5. Maximal amount of tryptophan injected onto column: $7.76 \mu \mathrm{g}$

${ }^{b}-S_{n}{ }^{219}, S_{11}{ }^{279}$ and $S_{n}$ : tryptophan peak areas obtained by the use of UV monitoring at 219 and $279 \mathrm{~nm}$, and fluorescence detection $\left(\lambda_{\mathrm{ex}} / \lambda_{\mathrm{cm}}=280 / 360 \mathrm{~nm}\right)$, respectively

seen from the data summarized in Table 4, the responses of detectors to the concentrations of tryptophan were linear functions for all monitoring modes. It seems clear from the LOD and LOQ values, fluorescent and UV responses that HPLC system II with UV detection at $219 \mathrm{~nm}$ is the most suitable for direct quantification of tryptophan. Moreover, the correlation coefficient and standard error in slope evidence that this short-UV detection is fully suitable for routine tryptophan analysis. The accuracy of the direct method was also assessed by examining the UV spectra (190-430 nm) of tryptophan in assayed biological samples and by determining relationships between the monitoring wavelength $\left(\lambda_{\mathrm{mm}}\right)$ and the ratios $\left(\mathrm{R}^{\mathrm{tin}}\right)$ (i.e. $\mathrm{R}^{\mathrm{nm}}=\mathrm{R}^{\mathrm{nm}}{ }_{\text {sample }} / \mathrm{R}^{\mathrm{nm}}{ }_{\text {standard }}$, for abbreviations see Table 5) (Czauderna and Kowalczyk, 2001). The ratios ( $\mathrm{R}^{\mathrm{nt}}$ ) ) of tryptophan for alkaline hydrolysate of pea seeds were nearly 1 in the UV range from 200 to $305 \mathrm{~nm}$ (i.e. the average $\pm S D$ ratio: $1.029 \pm 0.068)$. Similarly, for rumen bacteria Lachnospira multiparus $685(200 \mu \mathrm{l}$ of bacterial hydrolysate in $400 \mu$ l of water) spiked with tryptophan (18.7 and $149.6 \mu \mathrm{g}$ ), the ratios $\left(R^{\mathrm{um}}\right)$ were practically one (i.e. the average $\pm S D$ ratios were $0.891 \pm 0.206$ and $0.996 \pm 0.208$, respectively). Accuracy of the method was also assessed by examining the recovery of known quantities (from 18.7 to $150 \mu \mathrm{g}$ ) of tryptophan added to rumen bacteria samples $(200 \mu \mathrm{l}$ of bacterial hydrolysate in $400 \mu \mathrm{l}$ of water). The average $\pm S D$ recovery was $96.3 \pm 0.7 \%$, the correlation coefficient (r): 0.9996 , while the ratio of responses (slopes of regression calibration lines) of tryp- 
tophan peak area to the quantity of tryptophan added to water (standard) and to bacterial hydrolysate was close to 1 (i.e. in the two applied UV detection modes the average ratio was 0.96 ). It seems clear from the LOD and LOQ values that the proposed HPLC procedure (especially with detection at $219 \mathrm{~nm}$ ) offers satisfactory sensitivity permitting quantification very low levels of tryptophan (i.e. $0.8 \mathrm{ng}$ per HPLC analysis) when compared with original tryptophan contents in biological samples (e.g., in a pea seeds: $2.2 \mathrm{mg} / \mathrm{g} \mathrm{DM}$ ).

TABLE 5

Average $\pm S D$ of $R^{\mathrm{nm}}$ values ${ }^{\mathrm{a}}$ obtained in the $U V$ monitoring range of $314-360 \mathrm{~nm}$ for assayed biological samples

\begin{tabular}{|c|c|c|c|c|c|c|}
\hline Amino aciós & $\begin{array}{l}\text { Rumen } \\
\text { bacteria }\end{array}$ & $\begin{array}{l}\text { Duodenal } \\
\text { digesta }\end{array}$ & Faeces & $\begin{array}{c}\text { Blood } \\
\text { plasmah }\end{array}$ & Meat & Milk \\
\hline Cysteine & $-c$ & $-c$ & $-c$ & $\sim c$ & - & $0.97 \pm .20$ \\
\hline Aspatic acid & $0.95 \pm .06$ & $0.96 \pm .11$ & $0.98 \pm .02$ & $-c . d$ & $0.93 \pm .11$ & $0.93 \pm .12$ \\
\hline Glutamic acid & $1.01 \pm .01$ & $1.09 \pm .11$ & $1.08 \pm .16$ & $0.94 \pm .11$ & $1.07 \pm .18$ & $1.02 \pm .08$ \\
\hline Aspargine & $-c$ & $-c$ & $-c$ & $1.00 \pm .28$ & $-c$ & $0.98 \pm .15$ \\
\hline Histidine & $1.02 \pm .11$ & $1.02 \pm .02$ & $1.03 \pm .04$ & $1.02 \pm .23$ & $0.99 \pm .06$ & $0.98 \pm .06$ \\
\hline Serine & $1.01 \pm .01$ & $1.01 \pm .01$ & $1.00 \pm .01$ & $1.04 \pm .21$ & $1.01 \pm .05$ & $1.00 \pm .05$ \\
\hline Arginine & $1.00 \pm .01$ & $1.00 \pm .01$ & $0.99 \pm .02$ & $1.01 \pm .05$ & $0.99 \pm .06$ & $1.00 \pm .40$ \\
\hline Glycine & $1.00 \pm .01$ & $1.00 \pm .09$ & $1.01 \pm .01$ & $1.02 \pm .05$ & $0.99 \pm .10$ & $1.00 \pm .06$ \\
\hline Threonine & $1.01 \pm .01$ & $1.00 \pm .01$ & $1.06 \pm .01$ & $1.06 \pm .10$ & $1.00 \pm .05$ & $1.00 \pm .05$ \\
\hline Tyrosine & $1.00 \pm .01$ & $1.01 \pm .02$ & $1.01 \pm .01$ & $1.17 \pm .22$ & $1.00 \pm .06$ & $1.00 \pm .05$ \\
\hline Alanine & $1.01 \pm .01$ & $1.00 \pm .01$ & $1.00 \pm .0\}$ & $1.06 \pm .05$ & $1.00 \pm .03$ & $1.06 \pm .17$ \\
\hline Taurine & $1.01 \pm .11$ & $1.11 \pm .02$ & $1.06 \pm .04$ & $-c$ & $1.02 \pm .05$ & $-c$ \\
\hline Methionine & $0.98 \pm .05$ & $1.01 \pm .02$ & $1.02 \pm .05$ & $1.01 \pm .09$ & $1.04 \pm .16$ & $1.00 \pm .06$ \\
\hline Valine & $1.00 \pm .01$ & $1.00 \pm .02$ & $1.00 \pm .01$ & $1.01 \pm .04$ & $0.99 \pm .06$ & $0.99 \pm .06$ \\
\hline Phenylalanine & $1.00 \pm .01$ & $1.01 \pm .01$ & $1.00 \pm .01$ & $0.98 \pm .19$ & $1.00 \pm .06$ & $1.01 \pm .06$ \\
\hline $\mathrm{DAPA}^{\circ}$ & $1.00 \pm .01$ & $1.02 \pm .03$ & $1.02 \pm .03$ & $-c$ & $-c$ & $-c$ \\
\hline Isoleucine & $1.00 \pm 01$ & $1.00 \pm .01$ & $1.00 \pm .02$ & $1.06 \pm .11$ & $1.00 \pm .05$ & $1.01 \pm .05$ \\
\hline Cystine & $0.94 \pm .08$ & $1.02 \pm .08$ & $1.04 \pm .05$ & $-c$ & $0.96 \pm .07$ & $1.00 \pm .06$ \\
\hline Leucine & $0.99 \pm .01$ & $1.00 \pm .01$ & $1.00 \pm .01$ & $0.99 \pm .12$ & $0.99 \pm .05$ & $1.00 \pm .05$ \\
\hline Lysine & $1.03 \pm .04$ & $1.01 \pm .04$ & $1.04 \pm .04$ & $0.99 \pm .02$ & $0.99 \pm .05$ & $0.99 \pm .29$ \\
\hline
\end{tabular}

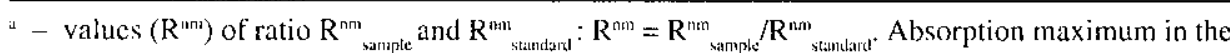

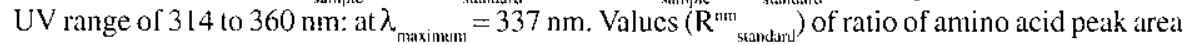

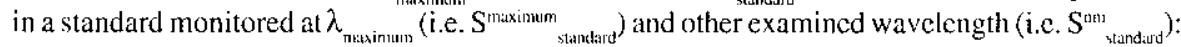

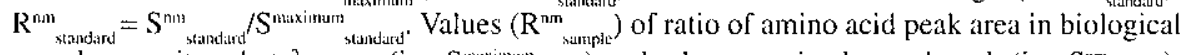
samples monitored at $\lambda_{\text {maximum }}$ (i.e. $S_{\text {sianple }}^{\text {maximum }}$ ) and other examined wavelength (i.e. $S^{\text {nmm }}{ }_{\text {sarmple }}$ ): $R_{\text {sumple }}^{\text {nim }}=S_{\text {sumple }}^{\text {num }} / S^{\text {maiximum }}$ samplec

b - determination of free amino acids in ovine blood plasma

- - below LOQ in examined UV range from $31410360 \mathrm{~nm}$ (above LOQ only in the proximity of 337 nm, i.e. $\pm \sim 10 \mathrm{~nm}$ )

$"$ - quntificated by fluorescence detection $\left(\lambda_{\mathrm{ex}} / \lambda_{\mathrm{elm}}=336 / 425 \mathrm{~nm}\right)$

e - 2,6-diaminopimelic acid 
Reliability of the HPLC system I

The development of a new HPLC method with UV detection for determining primary amino acids provided the impetus for its application to biological samples such as rumen bacteria, intestinal digesta, faeces, ovine meat, milk and blood plasma. In fact, amino acid analysis of these samples is of ongoing interest to physiological and nutritional research centres conducting nutritional studies. Thus, different detection modes were applied to check the resolution efficiency of amino acid peaks. Moreover, no co-elutions of amino acid peaks with unidentified species present in the examined samples were observed for UV detection in the spectral range of $300-370 \mathrm{~nm}$. The accuracy of gradient elution system I with PAD detection was proved by comparing UV spectra (from 190 to $400 \mathrm{~nm}$ ) of amino acids in standards and ones detected in assayed biological samples. The accuracy of the presented method was also investigated in detail by determining relationships between detecting wavelength $\left(\lambda_{\mathrm{m}}\right)$ and ratios $\left(\mathrm{R}^{\mathrm{nm}}\right)$ of the area of amino acid peaks in all assayed samples $\left(\mathrm{R}^{\mathrm{min}}{ }_{\text {sample }}\right)$ and a calibration standard $\left(\mathrm{R}^{\text {nin }}{ }_{\text {standird }}\right.$ ) (for abbreviations see in Table 5). As can be seen from data summarized in Table 5, all values for detected amino acids were practically equal to 1 . Considering the above results it is reasonable to conclude that all peaks corresponding to amino acids in all assayed biological samples were "pure" in the UV range of 314-360 nm, i.e., devoid of interference due to co-eluting peaks of endogenous species absorbing in the UV range used. Further detailed analysis of "peak purity" of amino acids of cow and goat milk revealed that all peaks corresponding to the assayed primary amino acids to be also pure in the UV range of $320-355 \mathrm{~nm}$. Thus, all amino acid peaks in the assayed samples can be integrated using the total peak area method. HPLC system I was also evaluated by analyzing recoveries of amino acid standards $(4.5,9.0$ and $13.5 \mathrm{nmol})$ added to $10 \mu \mathrm{l}$ of bactcrial hydrolysates. Poor precision of integration of some small amino acid peaks caused deviations of recovery values from $100 \%$. However, the obtained average recoveries of added amino acids were satisfactory (near $\sim 100 \%$ ), when UV and fluorescence detection were used.

As can be seen from the data summarized in Table 5, HPLC system I enables analysis of free amino acids in blood plasma. However, to enhance the separation of the lysine peak from unidentified species the water content needed to be increased. On increasing the water content of the eluent (in the last gradient step; see in Table 1), 31\% proved to be optimum of separation of lysine from interfering endogenous species present in plasma. Moreover, the presented HPLC system I with fluorescence detection assured better separation of glycine from threonine and significantly reduced the background under the lysine peak in comparison with the chromatographic conditions offered in our previously published HPLC method with fluorescence detection (Czauderna and Kowalczyk, 1998). 
No significant decreases (up to $5 \%$ ) of amino acid contents (with the exception of cysteine, cystine) in any assayed biological samples were observed when the derivatization solutions were protected from light and stored for $8-9$ days at $-18^{\circ} \mathrm{C}$. On the other hand, detailed investigations of the stability of the cysteine derivative proved that the cysteine peak disappeared practically after 1 day of storage at $-18^{\circ} \mathrm{C}$, while the cystine derivative was more stable, therefore, even after 8 days of storage at $-18^{\circ} \mathrm{C}$, about $1 / 5$ of the initial amount of derivatized cystine was detected. For all assayed biological samples stored for 8-9 days, HPLC chromatograms obtained using systems I and II with UV and fluorescence detection revealed that new unknown species formed but did not affect precise integration of analytical amino acid peaks. The reproducibility and reliability of the current HPLC systems were evaluated by repeat analysis of biological materials and blank samples. The low values of relative variations of amino acid peak areas (below $\pm 2 \%$ ) obtained for UV and fluorescence detection render HPLC systems I and II suitable for evaluating the primary amino acid profile in such important for nutritionists samples as meat, milk, blood plasma or intestinal digesta.

To enhance the resolution between derivatized cysteine and unidentified species present in biological materials, the methanol content of the mobile phase needed to be significantly reduced. Therefore, in order to obtain acceptable separation for OPA/ESH cysteine derivative the isocratic elution system $(9 \mathrm{~min}$ in $100 \%$ solvent $\mathrm{A}$ at a flow-rate of $2.2 \mathrm{ml} / \mathrm{min}$ ) with UV detection at $274 \mathrm{~nm}$ should be used (see Table 6). As shown in Figure 3 derivatized cysteine appeared in chromatograms as two peaks. Detailed analysis revealed that the optimum detection of the first larger cysteine peak was obtained using UV monitoring at $274 \mathrm{~nm}$, while the second smaller one was at $284 \mathrm{~nm}$ (i.e., measured at their maxims - see Figure 3). As expected, both OPA/ESH cysteine peaks cannot be identified applying fluorescence detection. Obviously, both derivatives were absent from the blank. As can be seen from results summarized in Table 6, the response of the UV detector to concentrations of cysteine in the standard was a linear function. Moreover, the correlation coefficient, the standard crror in slope, very low values of LOD and LOQ evidenced that the first cysteine peak and UV detection at $274 \mathrm{~nm}$ are the most suitable for routine cysteine analysis. The accuracy of cysteine quantification was also investigated by determining relationships between the monitoring wavelength $\left(\lambda_{\text {num }}\right)$ and ratios $\left(\mathrm{R}^{\mathrm{n} n}\right)$ of areas of both OPA/ ESH cysteine peaks in biological samples $\left(\mathrm{R}^{\mathrm{nm}}{ }_{\text {sample }}\right)$ and a calibration standard $\left(\mathrm{R}_{\text {standard }}\right.$ ). The obtained results (Table 6) demonstrated that the first largest peak was purer in comparison with the second smaller peak corresponding to derivatized cysteine, i.e., devoid of interference due to co-eluting peaks of endogenous species in the UV range of 260-305 nm. Probably, poor precision of integration of the first cysteine peak beyond the UV range of 260-305 nm (sce UV spectra in Figure 3) caused deviation of peak "purity" from 1. In summary, 
TABLE 6

Summary of the quantification of OPA/ESH cystcine derivatives obtained at $39^{\circ} \mathrm{C}$ elution temperature, in solvent A at a flow-rate of $2.2 \mathrm{ml} / \mathrm{min}$ (the isocratic HPLC system) ${ }^{\text {a }}$

\begin{tabular}{|c|c|c|}
\hline \multirow{3}{*}{ Parameter } & \multicolumn{2}{|c|}{ UV detection } \\
\hline & at $274 \mathrm{~nm}$ & at $284 \mathrm{~nm}$ \\
\hline & $\begin{array}{l}\text { The first peak } \\
(2.73 \pm 0.12 \mathrm{~min})^{\mathrm{b}}\end{array}$ & $\begin{array}{l}\text { The second peak } \\
(8.43 \pm 0.07 \text { min })^{b}\end{array}$ \\
\hline Linear regression curves ${ }^{c}$ & $y=1.1036 \cdot 10^{-6} S_{n}+0.31$ & $y=2.3368 \cdot 10^{5} S_{n}+0.31$ \\
\hline Correlation coefficicient ( $r$ ) & $0.9987^{\mathrm{n}}$ & $0.9970^{n}$ \\
\hline $\begin{array}{l}\text { Standard error } \\
\text { in slope (SES) }\end{array}$ & $1.32 \cdot 10^{.8}$ & $1.05 \cdot 10^{-6}$ \\
\hline $\begin{array}{l}\text { Limit of detection } \\
\text { (LOD) nmo[ } \cdot]^{-1}\end{array}$ & 0.8 & 1.2 \\
\hline $\begin{array}{l}\text { Limit of quantification } \\
(\text { LOQ) nmol. }]^{-1}\end{array}$ & 2.4 & 3.9 \\
\hline $\begin{array}{l}\text { Average } \pm S D \text { of } R^{\text {timl }} \text { values fo } \\
\text { milk } \\
\text { meat } \\
\text { ruminal bacteria }\end{array}$ & $\begin{array}{l}0.93 \pm 0.08 \\
0.93 \pm 0.07 \\
1.01 \pm 0.09\end{array}$ & $\begin{array}{c}1.11 \pm 1.00 \\
1.05 \pm 0.15 \\
\text { the concentration < LOQ }\end{array}$ \\
\hline
\end{tabular}

a - after 4 or 10 min (depending on used cysteine peak), the column was cleaned for $10 \mathrm{~min}$ in $95 \%$ methanol and $5 \%$ water at a flow-rate of $3 \mathrm{ml}$. Next the column should be re-equilibrated for $8 \mathrm{~min}$ in $100 \%$ solvent $\mathrm{A}$ at a flow-rate of $2.5 \mathrm{~min}$ (the column temperature: $39^{\circ} \mathrm{C}$ )

b - the retention times of derivatized cystene peaks: mean \pm SD of 8 HPLC samples

" $-S_{11}$ and $y$ are the peak area and derivatized cysteine amounts $(\mu \mathrm{mol})$ injected on to column, respectively. Multilevel forced through zero option for generation of lincar calibration curve fit Number of points used in the calibration curves: 5

a - averagc $\pm S D$ of $R^{m+n}$ values for the first peak in the UV range of 260-305, while for the second peak in the UV range of 260-316 nm

trace amounts of cysteine in biological samples should be quantified using the isocratic HPLC system and the larger peak of OPA/ESH derivatized cysteine as the basis of cysteine detection at $274 \mathrm{~nm}$.

\section{CONCLUSIONS}

The presented HPLC methods based on widely available $\mathrm{C}_{18}$ Nova Pak column and UV detection allow accurate and precise quantification of primary amino acids in biological materials such as feeds, bacteria produced in the rumen, intestinal digesta, meat and milk. In contrast with previous methods, OPA/ESH cysteine and cystine derivatives can be differentiated from other primary amino acids and simply quantified using HPLC system I with UV monitoring of the effluent at $337 \mathrm{~nm}$. 


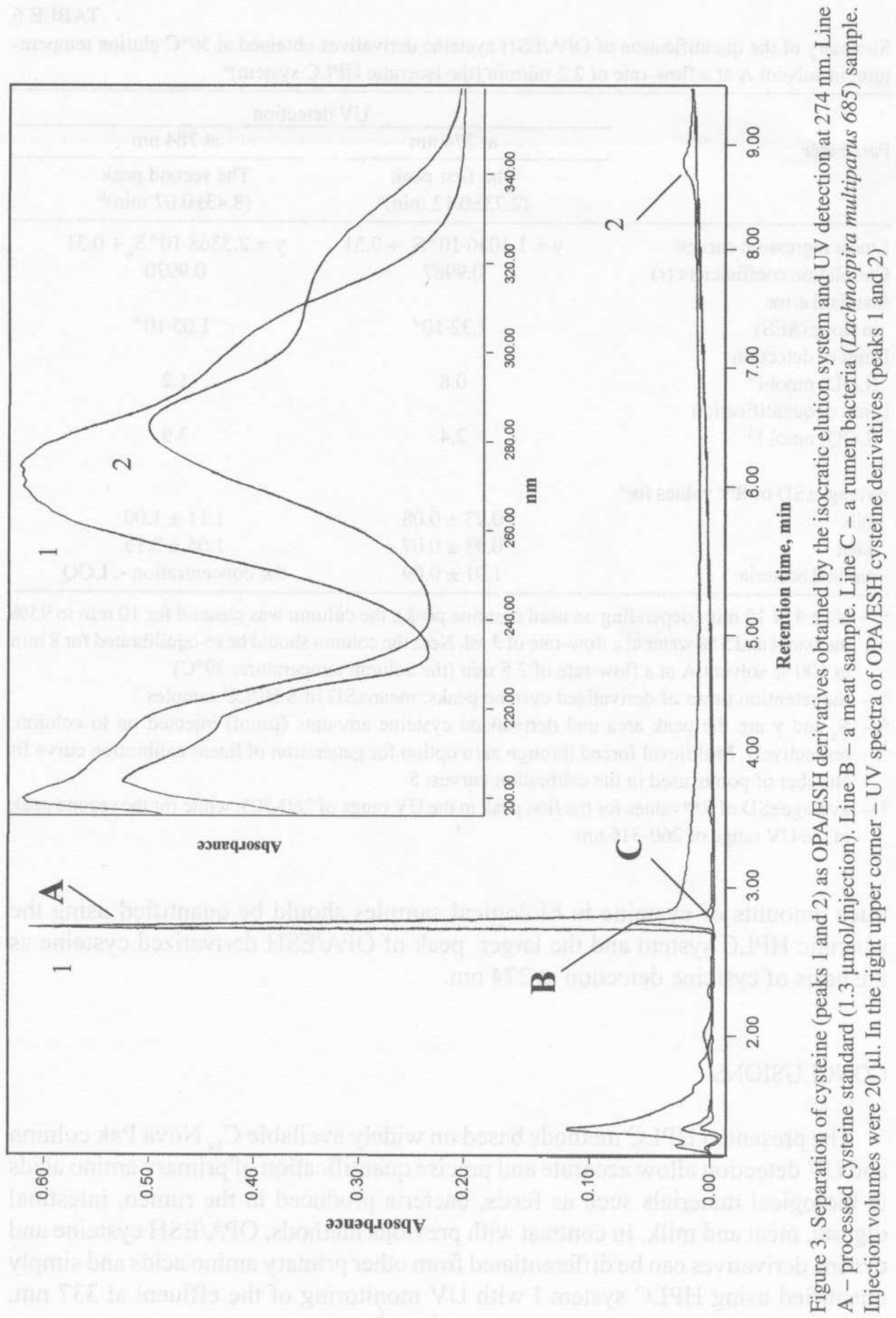


Obviously, these amino acid derivatives cannot be detected using fluorescence detection. We found many species in assaycd biological samples with the characteristic spectra of OPA/ESH amino acids of unknown origin. Thus, in this respect, the quaternary gradient system I with UV detection was chosen as the optimum condition for fractionation of all assayed OPA/ESH amino acids in examined biological samples hydrolyzed with $6 \mathrm{M} \mathrm{HCl}$. Consequently, our system I with UV detection gives satisfactory separation and sensitivity of free primary amino acids analysis in blood plasma samples.

Due to lack of direct OPA reactivity with imino acids (secondary amino acids) like proline or hydroxyproline, these amino acids should be oxidized with sodium hypochlorite (Czauderna and Kowalczyk, 1998) and next separated as OPA derivatives using RP-HPLC systems. Moreover, this oxidizing agent oxidized cyst(e)ine to cysteic acid that reacts with OPA/ESH to form an OPA-cysteic acid derivative possessing, like other primary amino acids, relatively high absorbance band in the UV spectral range from 310 to $360 \mathrm{~nm}$. The separation and quantification of oxidized proline, hydroxyproline and cyst(e)ine, as their OPA/ESH derivatives, can be achieved applying a Symmetry $\mathrm{C}_{18}$ column $(5 \mu \mathrm{m}, 250 \times 4.6 \mathrm{~mm}$, I.D., Waters $)$ and UV detection at $\sim 337 \mathrm{~nm}$ (Czauderna and Kowalczyk, 1998). Obviously, secondary amino acids may be derivatized with other reagents (e.g., 4-chloro-7-nitrobenzofurazan or 9-fluorenylmethyl chloroformate), and then separated using the HPLC systems reported by Umagat (1982) or by Sarwar (1993). Moreover, methionine and cyst(e)ine estimation in biological materials hydrolysed with hydrochloric acid show that certain amount of cyst(e)ine and methionine can be oxidized. Therefore, the preparation procedure should be incorporated an oxidation step to convert these amino acids to respectively cysteic acid and methionine sulphone prior to hydrolysis and derivatization (Rattenbury, 1981; Buraczewska and Buraczewski, 1984).

The presented HPLC systems with UV detection can be possible reliable alternatives to earlier chromatographic methods with fluorescence detection.

\section{REFERENCES}

Albin D.M., Wubben J.E., Gabert V.M., 2000. The influence of hydrochloric acid concentration and measurement method on the determination of amino acid levels in soya bean products. Anim. Feed Sci. Tech. 87, 173-186

Batterham E.S., 1992. Availability and utilization of amino acids for growing pigs. Nutr. Res. Rev. 5, 1- 18 Buraczewska L., Buraczewski S., 1984. A note on the determination of methionine and tryptophan. In: Proceedings of the VI International Symposium on Amino Acids.Polish Scientific Publishers, Warsaw, pp. 47-50

Cohen S.A., Michaud D.P., 1998. Highly accurate, high sensitivity amino acid analysis with novel activated carbamates as pre-column derivatizing reagent. Millipore, Waters Chromatography Division. Milford, Massachusetts (USA) 
Czauderna M., Kowalczyk J., 1998. Determination of free amino acids in blood plasma by highperlormance liquid chromatography with fluorescence detection. J. Anim. Feed Sci. 7, 453-463

Czauderna M., Kowalczyk J., 1999. Determination of 2,6-diaminopimelic acid in bacteria, ruminal and duodenal digesta using HPLC with fluorescence or UV detection. J. Anim. Feed Sci. 8, 273288

Czauderna M., Kowalczyk J., 2001. Separation of some mono-, di- and tri-unsaturated fatty acids containing 18 carbon atoms by high-performance liquid chromatography and fotodiode array detection. J. Chromatogr. B 760, 165-178

Gratzfeld-Husgen A., Schuster R., 1996. HPLC for Food Analysis. Hewllett-Packard (Germany), p. 117

Kutlan D., Molnar-Perl I., 2001. Characteristics and stability of the OPA/3-mercaptopropionic acid and OPA/N-acctyl-L-cysteine derivatives of amino acids. Chromatographia 53, Suppl., S188S 198

Lewis A.J., Bayley H.S., 1995. Amino acid bioavailability. In: C.B. Ammerman, D.H. Baker, A.J. Lewis (Editors). Bioavailability of Nutrients for Animals. Academic Press, pp. 35-65

McKerrow J., Vagg S., McKinney T., Seviour E.M., Maszenan A.M., Brooks P., Seviour R. J., 2000. A simple HPLC method for analysing diaminopimelic acid diastereomers in cell walls of grampositive bacteria. Lett. Appl. Microbiol. 30, 178-182

Meyer V.R., 1999. Practical High-Performance Liquid Chromatography. John Wiley and Sons, Chichester (UK), p. 78

Moller S.E., 1993. Quantification of physiological amino acids by gradient ion-exchange high performance liquid chromatography. J. Chromatogr. 613, 223-230

Molnar-Perl I., 2001. Derivatization and chromatographic behavior of the o-phthaldialdehyde amino acid derivatives obtained with various SH-group-containing additives. J. Chromatogr. A 913 , 283-302

Ng L.T., Wong D.Y., Francis T., Anderson G.H., 1991. Ion-exchange chromatography for physiological 1luid amino acid analysis. J. Nutr. Biochem. 2, 671-679

Peter A., Torok G., Armstrong D.W., 1998. High-performance liquid chromatographic separation of enantiomers of unusual amino acids on a teicoplanin chiral stationary phase. J. Chromatogr. 793, 238-296

Polak B., Golkiewicz. W., 2000. Retention and selectivity of amino acid cster derivatives on (R)-N(3,5-dinitrobenzoyl)-phenylglycine column. J. Lią. Chromatogr. Relat. Techno. 23, 2807-2818

Rattenbury J.M., 1981. Amino Acid Analysis. John Wiley and Sons, New York, pp. 37-47, 66-70

Ravindran V., Bryden W.L., 1999. Amino acid availability in poultry - in vitro and in vivo measurements. Aust. J. Agr. Res. 50, 889-908

Robinson P.H., Fadel J.G., Ivan M., 1996. Critical evaluation of diaminopimelic acid and ribonucleic acid as markers to estimate rumen pools and duodenal flows of bacterial and protozoal nitrogen. Can. J. Anim. Sci. 76, 587-597

Sarwar G., Botting H.G., 1993. Evaluation of liquid chromatographic analysis of nutritionally important amino acids in food and physiological samples. J. Chromatogr. 615, I-22

Umagat H., Kucera P., Wen L.-F., 1982. Total amino acid analysis using pre-column fluorescence derivatization. J. Chromatogr. 239, 463-474

Williams A.P., 1994. Recent developments in amnino acid analysis. In: J.P.F. D’Mello (Editor). Amino Acids in Farm Animal Nutrition. CAB International: Wallingford (UK), pp. 11-36

Żebrowska T., Buraczewski S., 1998. Methods for determination of amino acids bioavailability in pig - Review. Asian-Austr. J. Anim. Sci. 11, 620-633 


\section{STRESZCZENIE}

Oznaczanie wolnych $\mathbf{i}$ bialkowych aminokwasów w materiałach biologicznych metodą wysokosprawnej chromatografii cieczowej $z$ detekcją fotodiodową

W pracy opisano metodę oznaczania wolnych i białkowych pierwszorzędowych aminokwasów w materiałach biologicznych, które hydrolizowano w $6 \mathrm{M} \mathrm{HCl}$ przez 20 godzin w temperaturze $104 \pm 2{ }^{\circ} \mathrm{C}$. Po odparowaniu hydrolizatu aminokwasy przeprowadzano $w$ pochodnc używając o-dialdehyd ftalowy w obecności etanotiolu. Pochodne aminokwasów rozdzielano na kolumnie $\mathrm{C}_{18}$ z odwróconą fazą (Nova-Pak, $4 \mu \mathrm{m}, 250 \times 4.6 \mathrm{~mm}$ ) poprzez poczwórną elucje gradientową. Pochodne oznaczano stosując monitorowanie UV przy $337 \mathrm{~nm}$ lub detekcję fluorescencyjną (wzbudzenie $336 \mathrm{~nm}$, porniar $425 \mathrm{~nm}$ ). Czas rozdzielenia wszystkich aminokwasów wynosił po $50 \mathrm{~min}$. Prezentowana metoda (system I) może być również użyta do oznaczania wolnych aminokwasów we krwi owiec. Oznaczanie śladowych ilości cysteiny można przeprowadzić po $3.5 \mathrm{~min}$. izokratycznej elucji wykorzystując monitorowanic UV przy $274 \mathrm{~nm}$. Tryptofan w badanych próbach oznaczono po 16 godz. hydrolizie alkalicznej w $\mathrm{Ba}(\mathrm{OH})_{2}$. Po usunięciu jonów baru i doprowadzeniu pH hydrolizatu do wartości $\sim 7$, tryptofan oznaczano bezpośrednio wykorzystując tę samą kolumnę, potrojną clucję gradientową oraz monitorowanic UV przy $219 \mathrm{~nm}$ lub detekcję fluorescencyjna (wzbudzenie: 280 $\mathrm{nm}$; pomiar: $360 \mathrm{~nm}$ ). Średni odzysk standardów aminokwasów dodanych do próbek biologicznych był bliski 100\% zárówno przy monitorowaniu UV jak i przy detekcji fluorescencyjnej. Detekcja fluorescencyjna pozwala na uzyskanic lepszych wartości granic jakościowej i ilościowej detekcji w porównaniu z detekcją UV. Czułość detekcji UV oraz „czystość analitycznych pików” jest wystarczająca do rutynowego oznaczania pierwszorzędowych aminokwasów w masic bakteryjnej, treści przewodu pokarmowego owicc, kale, mięsie oraz mleku. Prezentowana metoda HPLC może być wykorzystana do oceny rozmiaru biosyntezy białka bakteryjnego. 